\title{
EVALUATION OF SOME ENTOMOPATHOGENS ON THE RED PALM WEEVIL, RHYNCHOPHORUS FERRUGINEUS UNDER LABORATORY AND FIELD CONDITIONS
}

\author{
ALI M. A. ${ }^{1 *}$, H. K. BEKHIET ${ }^{1}$, D. A. RAGHEB ${ }^{2}$ and A. A. EL-FESHAWAY ${ }^{2}$ \\ 1. Plant Prot. Inst., ARC, Dokki, Giza, Egypt \\ 2. Plant Prot. Dept., Fac. Agric., Zagazig Univ., Egypt \\ * Corresponding author: Tel. : +201065053461 E-mail address: abdelsalam eg@yahoo.com
}

(Manuscript received 28 August 2017)

\begin{abstract}
$\mathrm{T}$ he present study was carried out at El-Kassasin district Ismailia Governorate, Egypt to evaluate the efficiency of three entomopathogens (Heterorhabditis. bacteriophoraHP-88, Metarhizium anisopliae and Bacillus thuringiensis subsp. Kurstaki ) against of the red palm weevil, Rhynchophorus ferrugineus under laboratory and field conditions. The results revealed that Heterorhabditis bacteriophoraHP-88 was most virulent to the red palm weevil, Rhynchophorus ferrugineus under laboratory conditions. On the other hand, the activity of $M$. anisopliae and $B$ thuringiensis subsp. Kurstaki against red palm weevil were low. However, field experiments indicated that $H$. bacteriophoraHP-88, M. anisopliae and B. thuringiensis subsp. kurstaki had no external sign of recovery from the infestation levels.

Key words: Rhynchophorus ferrugineus, bioassay, entomopathogens, Metarhizium anisopliae, Heterorhabditis bacteriophora, Bacillus thuringiensis.
\end{abstract}

\section{INTRODUCTION}

The red palm weevil, Rhynchophorus ferrugineus is known as the most destructive pest to date, coconut and oil palms in Arabic region and south East Asia (Hanounik, 1998). It has been known first in south east Asia until it appeared in United Arab Emirates in 1985, Kingdom of Saudi Arabic in 1987 and Egypt in 1992.

The use of biological control agents in the management of insect pests has increased in recent years. However, there are now deep concerns about environmental pollution and health risks associated with use of chemical insecticides. Among biological control measures are the entomopathogenic fungi which there are potential and environmentally safe to invertebrates and plant species in addition to their wide use in control of many insect pests. Gindin et al., (2006) and El-Sufty et al., (2007) recommended using the fungi in the management programs of $R$. ferrugineus.

Bacillus thuringiensis is among the most successful biological control agents for the suppression of agriculturally and medically important insect pests being toxic to the larvae of lepidopteron, dipteran and coleopteran insects. The efficacy of the 
entomopathogenic bacterium $B$. thuringiensis to control red palm weevil, $R$. ferrugineus has been tested in laboratory conditions (Manachini et al., 2011). Although there were evidences indicating midgut damage and feeding inhibition among larvae that survived the treatments.

Entomopathogenic nematodes are effective in controlling a variety of economically important pests including the larvae of several weevil species (Coleoptera: Curculionidae) such as the black vine weevil, Otiorhynchus sulcatus (F.), and the Diaprepes root weevil, Diaprepes abbreviatus (L.) (Shapiro-Ilan et al., 2002). When applied in the laboratory, nematodes are capable of causing host death within 24-48 h; however, under field conditions pest control can be somewhat more unpredictable.

The aim of the present study was to test the susceptibility of the red palm weevil to the entomopathogenic fungus (M. anisopliae), entomopathogenic bacteria (B. thuringiensis subsp. kurstakl) and entomopathogenic nematode ( $H$. bacteriophoraHP-88) to provide information help in integrated control program for the red palm weevil.

\section{MATERIALS AND METHODS}

\section{Red Palm Weevil, Rhynchophorus ferrugineus}

The red palm weevil, $R$. ferrugineus were reared under laboratory conditions at $28 \pm 11^{\circ} \mathrm{C}$ and $60-70 \%$ R.H. Adult weevils were collected from infested date palm trees at a plantation located at El-Kassasin district, Ismailia Governorate, Egypt. Rearing of the red palm weevil maintained on the stems of sugarcane as described by Kaakeh et al. (2001).

\section{Entomopathogens:}

\subsection{Metarhizium anisopliae (Metchnikoff).}

Fresh slant culture M. anisopliae Sorokin was obtained from Insect pathogen Unit at Plant Protection, Research Institute, Agricultural Research Center, Dokky, Giza, Egypt.

The conidia fungus were cultured on agar Petri dishes of Dox medium (Thom and Raper., 1945). The medium consists of Sucrose $20 \mathrm{~g} / \mathrm{L}$, $\mathrm{KHPO}_{4} 1 \mathrm{~g} / \mathrm{L}, \mathrm{KNO}_{3} 2 \mathrm{~g} / \mathrm{L}, \mathrm{KCl} 0.5 \mathrm{~g} / \mathrm{L}$, Yeast extract $2 \mathrm{~g} / \mathrm{L}, \mathrm{MgSO}_{4} .7 \mathrm{H}_{2} \mathrm{O} 0.5 \mathrm{~g} / \mathrm{L}$, $\mathrm{FeSO}_{4} .7 \mathrm{H}_{2} \mathrm{O} 0.002 \mathrm{~g} / \mathrm{L}$ and agar $20 \mathrm{~g} / \mathrm{L}$ and incubated at $25 \pm 2{ }^{\circ} \mathrm{C}$ and $60-70 \%$ R.H for two weeks. At the end of incubation period the conidia were harvested from the surface of the culture directly by scraping with sterile solution of $0.02 \%$ Tween- 80 . The conidia were separated by filtration through sterilized glass-wool. For experimental work, conidia of $B$. bassiana-9894 were suspended in $50 \mathrm{ml}$ sterile 
distilled water with $0.02 \%$ Tween-80 and vortexes for 1 minute to break spore chains into individual spores and assure uniform mixing. Spores suspended in sterilized water were counted using haemocytometer counts technique.

\subsection{Entomopathogenic bacteria Bacillus thuringiensis subsp. Kurstaki.}

Fresh slant culture $B$. thuringiensis subsp. kurstaki was obtained from Insect pathogen Unit at Plant Protection Research Institute, Agricultural Research Center, Dokky, Giza, Egypt.

Culture condition of B.t subsp. kurstaki were carried out according to Attathom et al. (1995). T3 agar medium was prepared which composed of tryptone $3.0 \mathrm{~g}$; tryptose $2.0 \mathrm{~g}$; yeast extract $1.5 \mathrm{~g} ; \mathrm{MnCl}_{2} 0.005 \mathrm{~g} ; \mathrm{NaH}_{2} \mathrm{PO}_{4} \mathrm{H}_{2} \mathrm{O} 9 \mathrm{~g}$ and agar $15 \mathrm{~g}$, adjust $\mathrm{pH}$ To 6.8. The final volume was made up to 1 liter with distilled water and poured in test tubes and Petri dishes (7-9 ml/tube or dish). The tubes and the Petri dishes were sterilized at $121^{\circ} \mathrm{C}$ for 20 minutes in the autoclave. Tubes and Petri dishes were inoculated with $B$. thuringiensis subsp. kurstaki and incubated for $72 \mathrm{~h}$ at $30^{\circ} \mathrm{C} \pm 1$ and $50-60 \%$ R.H.

At the end of the incubation period, the resulted spores were harvested from the surface of the culture directly by scraping with sterile solution. Then, resulting spores in a suspension were counted using the haemocytometer counts technique. Five concentrations were prepared i.e., $3 \times 10^{9}, 3 \times 10^{8}, 3 \times 10^{7}, 3 \times 10^{6}$ and $3 \times 10^{5}$ spores / $\mathrm{ml}$ using distilled water and $0.01 \%$ tween- 80 .

\subsection{Entomopathogenic nematode Heterorhabditis bacteriophora-HP-88.}

The entomopathogenic nematode, H. bacteriophora-HP-88 was obtained from stock culture maintained for several generations in the laboratory of the Department of Pest Physiology, Plant Protection Research Institute, Agricultural Research Center, Dokky, Giza, Egypt.

The last instars larvae of G. mellonella Fabr. (Lepidoptera: Pyralidae) were used to multiply the IJs nematodes, following the methods described by Kaya and Stock (1997). Add to the larvae were topically inoculated with IJs using a micropipette, and subsequently incubated at $24 \pm 2^{\circ} \mathrm{C}$ in a dry chamber until they presented symptoms of infection. H. bacteriophora-HP-88 was left for 10-13 days before being put onto a White trap. The larvae were then placed in "White traps" to stimulate IJs emergence. When IJs emerged they were harvested every two days and washed three times in $500 \mathrm{ml}$ of tap water. Suspensions were stored in $25-30 \mathrm{ml}$ of sterilized distilled water at a concentration of $2000 \mathrm{IJs} / \mathrm{ml}$ and stored at $9^{\circ} \mathrm{C}$ for no more than two weeks before they were used. The considered concentrations were $250,500,1000,1500$ and $2000 \mathrm{IJ} / \mathrm{ml}$. 


\section{Virulence assays.}

\subsection{Laboratory evaluations of effectiveness of entomopathogens against the red palm weevil.}

The effectiveness of $M$. anisopliae against the eggs, larval instars, pupae and adults of the red palm weevil was evaluated. Whereas, the larval instars were exposed to the bacteria, B.t subsp. Kurstaki. While the nematode, $H$. bacteriophora-HP-88 was tested against the larval and adult stages.

\subsubsection{Pathogenicity of M. anisopliae.}

A serial of concentrations of the two tested fungi were prepared from stock solution in distilled water and $0.02 \%$ Tween- 80 . The considered concentrations were $3 \times 10^{5}, 3 \times 10^{6}, 3 \times 10^{7}, 3 \times 10^{8}$ and $3 \times 10^{9}$ spores $/ \mathrm{ml}$. The experiments were conducted in plastic cups $(9 \times 3 \mathrm{~cm})$ as described by Dembilio et al. (2010).

\subsubsection{Eggs exposure.}

For bioassay, eggs (1-4 days old) were obtained from egg-laying cages. Ten eggs were placed in each plastic boxes containing $5 \mathrm{~g}$ sugar cane sawdust. The sawdust was sprayed with fungal spore suspensions $\left(3 \times 10^{5}, 3 \times 10^{7}\right.$ and $3 \times 10^{9}$ spores $/ \mathrm{ml}$ ) or an aqueous solution of $0.02 \%$ Tween- 80 as control (both at a rate of $0.2 \mathrm{ml}$ per gram of sawdust) and well mixed. The boxes with eggs were incubated for 7 days at $28^{\circ} \mathrm{C}$ in darkness and inspected every day for egg hatching. The eggs bioassay was repeated four times.

\subsubsection{Larvae exposure.}

Groups of five larvae fourth, eighth and eleventh larval instars were directly immersed for $60 \mathrm{~s}$ in a conidia aqueous suspension of either $3 \times 10^{9}, 3 \times 10^{8}, 3 \times 10^{7}$, $3 \times 10^{6}$ and $3 \times 10^{5}$ spores $/ \mathrm{ml}$, and transferred onto plastic boxes ( 5 larvae per box) containing filter paper for $24 \mathrm{~h}$ then transferred onto plastic boxes containing $50 \mathrm{~g}$ of moist sugar cane sawdust and succulent pieces of sugarcane stems and incubated at $28^{\circ} \mathrm{C}$. Both treated and control solution contained $0.02 \%$ Tween-80. Four replicates of 5 larvae per concentration were treated. The larvae were examined after 2, 4, 6, 8, $10,12,14$ days and dead ones were recorded and removed. Values of $\mathrm{LC}_{50}$ were computed at 14 days exposure period by Probit analyses (Finney, 1971). Furthermore, median lethal time $\left(\mathrm{LT}_{50}\right)$ values were calculated for each treated concentration using log time/Probit relationship.

\subsubsection{Pupae and Adult exposure.}

Groups of five pupae (7 days post pupation) or adults (full grown adult, approximately one week post emergence) were immersed for $60 \mathrm{~s}$ in $50 \mathrm{ml}$ of a conidia aqueous suspension of either $3 \times 10^{9}, 3 \times 10^{8}, 3 \times 10^{7}, 3 \times 10^{6}$ and $3 \times 10^{5}$ spores $/ \mathrm{ml}$ or in a control aqueous solutions. Both control and treated solutions contained $0.02 \%$ 
Tween-80. Four replicates per concentration were considered. Subsequently each treated or control weevils was placed in a plastic box with $50 \mathrm{~g}$ of moist sugar cane sawdust, and incubated at $28^{\circ} \mathrm{C}$ under a 12:12 L:D regime for 2-3weeks. Fresh substrate was added to the boxes every week. The adults were examined after 2, 4, $6,8,10,12,14$ days and dead ones were recorded and removed. In case of pupae, were inspected at the same time for emergence adults. Values of $\mathrm{LC}_{50}$ were computed at 14 days exposure period by Probit analyses (Finney, 1971). Furthermore, median lethal time $\left(L T_{50}\right)$ values were calculated for each treated concentration using log time/Probit relationship.

\subsubsection{Effectiveness of bacteria Bacillus thuringiensis subsp. kurstaki.}

The experiments were conducted in plastic cups as mentioned before (4.1.1). The shreds of sugarcane were soaked for $30 \mathrm{~s}$ in a suspension of known concentrations of the tested isolate and then left to dry singly in plastic cups. Groups of instars larvae $\left(4^{\text {th }}, 8^{\text {th }}\right.$ and $\left.11^{\text {th }}\right)$ were confined with treated pieces of sugarcane and incubated at $28{ }^{\circ} \mathrm{C}$. Four replicates of 5 larvae per concentration were treated. Observations on larval mortality were recorded after 7 days of treatment. Larvae fed on untreated sugarcane shreds were used as control. Mortality percentages were recorded and the LC 50 's were calculated at 7 days post-treatment by Probit analyses (Finney, 1971).

\subsubsection{Effectiveness of the nematode, $H$. bacteriophora-HP-88 treatment.}

A virulence assay based on the methods described by Shapiro-Ilan et al. (2004) was carried out. After washing with distilled water $4^{\text {th }}, 8^{\text {th }}, 11^{\text {th }}$ instars larvae and adults were expose to $50 \mathrm{ml}$ water suspension of entomopathogenic nematode at 250, 500, 1000, 1500 and $2000 \mathrm{IJs} / \mathrm{ml}$ in plastic cup $(9 \times 3 \mathrm{~cm})$ lined with moist Whatman No. 1 filter paper. Each cup contained 5 larvae or adults replicated 4 times for every treatment. Water was used for control treatment. Cups were covered with an aerated lid and incubated at $28^{\circ} \mathrm{C}$. Observations were recorded after 24 hour till 9 days post-treatment. Cadavers were transferred individually to a white trap to determine the emergence of new generation of IJs. Values of $\mathrm{LC}_{50}$ were computed at 9 days exposure period by Probit analyses (Finney, 1971). Furthermore, median lethal time $\left(\mathrm{LT}_{50}\right)$ values were calculated for each treated concentration using log time/Probit relationship.

\section{Field evaluations of the effectiveness of the entomopathogens against the red palm weevil, $R$. ferrugineus.}

Field applications were conducted on 17 Fadden's containing 1134 date palm, P. dactylifera. The field plantation included naturally RPW infested and non-infested 
palm trees ranging in age between $7-12$ years $(5 \times 6 \mathrm{~m}$ between palms) at El-Kassasin area, Ismailia Governorate, Egypt. Infested date palms were marked at the start of the experiments.

\subsection{Injection of fungus, $M$. anisopliae suspension in palm trees.}

A stock solution of the fungal formulation was prepared $(2 \mathrm{~g} \mathrm{M}$. anisopliae spores suspended in $100 \mathrm{ml}$ sunflower oil and $0.02 \%$ Tween-80 and then sterilized distilled water was added to make 1 liter and well mixed). The trees infested of the surface were chosen to be injected with suspension of fungus, M. anisopliae. Seven trees were treated with water suspension of tested fungus at a concentration of $10^{8} / \mathrm{ml}$. Each tree infestation received approximately 2 liter of M. anisopliae preparation. Infestation sites were observed weekly for recovery (complete drying).

\subsection{B. thuringiensis subsp. kurstaki injection.}

The surface-infested trees were injected with suspension of bacterium. Five trees treated with water suspension of tested bacteria at a concentration of $10^{8} / \mathrm{ml}$. Each tree infestation received approximately 2 liter of bacterium preparation. Infestation sites were observed weekly till recovery (complete drying).

\subsection{Nematode injection.}

Infested trees on the surface were injected with infected juveniles. Five trees treated with water suspension of tested nematode at a concentration of $2000 \mathrm{IJs} / \mathrm{ml}$. Each tree infestation received approximately 2 liter of nematode preparation. Infestation sites were observed weekly till recovery (complete drying).

\section{Analysis of results.}

Insect mortality was recorded daily and corrected by Abbott's formula (Abbott, 1925). Mortality regression lines were estimated according to Finney (1971) using "LdPLine ${ }^{\circledR "}$ software to determine $\mathrm{LC}_{50}$, as well as the slope and regression values. In addition, the time required to kill $50 \%$ of the target insect ( $\left.L T_{50}\right)$ was also calculated for each treated developmental stage using log time/Probit relationship.

\section{RESULTS AND DISCUSSIONS}

\section{Laboratory evaluations of the effectiveness of the entomopathogens against the red palm weevil.}

The effectiveness of $M$. anisopliae against the eggs, larval instars, pupae and adults of the red palm weevil was evaluated. Whereas, the larval instars were exposed to the bacteria, B.t subsp. Kurstaki. While the nematode, $H$. bacteriophora-HP-88 was tested against the larval and adult stages. 


\subsection{Pathogenicity of the entomopathogenic fungus, $M$. anisopliae isolate to the red palm weevil, $R$. ferrugineus.}

Data in Table (1) represent the effect of $M$. anisopliae on different developmental stages of the red palm weevil. The newly laid eggs were treated with different concentrations of $M$. anisopliae $\left(3 \times 10^{9}, 3 \times 10^{8}, 3 \times 10^{7}, 3 \times 10^{6}\right.$ and $3 \times 10^{5}$ spores $/ \mathrm{ml}$ ). which gave the mortality percent $46.64,35.40,25.32,16.97$ and $10.65 \%$ resectivily, at the corresponding concentrations after 7-9 days post-treatment (Table 1).

Meanwhile, Gindin et al. (2006) found that $80 \%$ mortality of the tested eggs of $R$. ferrugineus with the entomopathogenic fungus, $M$. anisopliae using $1 \times 10^{8}$ spores/ml. Efficacy of $M$. anisopliae concentrations against RPW larval, pupal and adult stages is represented in Table (1). The different stages of the red palm weevil showed less susceptibility to $M$. anisopliae isolate.

Data in Table (1) showed that mortality of treated $4^{\text {th }}$ instar larvae ranged from 0.13 to $34.77 \%$ after 14 days post treatment when treated with the lowest and highest concentrations, respectively.

On the other hand, mortality did not occur in the $8^{\text {th }}, 11^{\text {th }}$ instar larvae and pupa stages within any of the tested concentrations of fungal isolate.

As for adults, the bioassay experiments indicated that the mortality of $R$. ferrugineus was differed according to the fungus concentrations. Mortality percentages was ranged between 0.03 and $20.58 \%$ when treated with the lowest and highest concentration of $M$. anisopliae. According to results in Table (2) the LC $\mathrm{C}_{50}$ values for $4^{\text {th }}$ instar larvae and adults were $1.3 \times 10^{10}$ and $3.1 \times 10^{10} \mathrm{spores} / \mathrm{ml}$, respectively.

Table 1. Accumulative mortality of different stages of red palm weevil using $M$.

\begin{tabular}{|c|c|c|c|c|c|c|}
\hline \multirow{2}{*}{$\begin{array}{c}\text { Concentration } \\
\text { Spores/ml }\end{array}$} & \multicolumn{7}{|c|}{$\%$ mortality of developmental stage* } & \\
\cline { 2 - 7 } & Eggs & $\begin{array}{c}4^{\text {th }} \text { instar } \\
\text { larvae }\end{array}$ & $\begin{array}{c}8^{\text {th }} \text { instar } \\
\text { larvae }\end{array}$ & $\begin{array}{c}11^{\text {th }} \text { instar } \\
\text { larvae }\end{array}$ & Pupae & Adults \\
\hline $3 \times 10^{9}$ & 46.64 & 34.77 & 0.00 & 0.00 & 0.00 & 20.58 \\
\hline $3 \times 10^{8}$ & 35.40 & 14.79 & 0.00 & 0.00 & 0.00 & 7.01 \\
\hline $3 \times 10^{7}$ & 25.31 & 4.46 & 0.00 & 0.00 & 0.00 & 1.66 \\
\hline $3 \times 10^{6}$ & 16.97 & 0.93 & 0.00 & 0.00 & 0.00 & 0.27 \\
\hline $3 \times 10^{5}$ & 10.65 & 0.13 & 0.00 & 0.00 & 0.00 & 0.03 \\
\hline
\end{tabular}

* Data were recorded after 14 days post treatment. 
Table 2. LC 50 values of $M$. anisopliae against instar larvae and adults of the red palm weevil.

\begin{tabular}{|c|c|c|c|c|c|}
\hline \multirow{2}{*}{$\begin{array}{c}\text { Developmental } \\
\text { stages }\end{array}$} & \multirow{2}{*}{$\begin{array}{c}\mathrm{LC}_{50} \\
\text { (spores/ml) }\end{array}$} & \multicolumn{2}{|c|}{$95 \%$ fiducial limits } & \multirow{2}{*}{ Intercept } & \multirow{2}{*}{ Slope } \\
\hline & & Lower & Upper & & \\
\hline Eggs & $5.8 \times 10^{9}$ & - & - & - & $\begin{array}{c}0.290 \pm \\
0.102\end{array}$ \\
\hline $4^{\text {th }}$ instar larvae & $1.3 \times 10^{10}$ & $2.3 \times 10^{9}$ & $6.3 \times 10^{12}$ & $\begin{array}{c}1.763 \pm \\
0.749 \\
\end{array}$ & $\begin{array}{r}0.631 \pm \\
0.200 \\
\end{array}$ \\
\hline Adults & $3.1 \times 10^{10}$ & $4.3 \times 10^{9}$ & $1.1 \times 10^{16}$ & $\begin{array}{c}0.854 \pm \\
1.306\end{array}$ & $\begin{array}{c}0.756 \pm \\
0.326\end{array}$ \\
\hline
\end{tabular}

Merghem (2011) found that the fungus effectively killed the red palm weevil stages. Gindin et al. (2006) reported that M. anisopliae strains caused mortality up to $80-100 \%$ of the larvae and adult weevils under laboratory conditions. Positive results in the biological control of red palm weevil were also obtained by Vitale et al. (2009) using a commercial product of $M$. anisopliae mixed with $B$. bassiana, whereas the use of $B$. bassiana only, isolated from a dead RPW, was not successful in killing the adults.

\subsection{Pathogenicity of entomopathogenic bacterium, $B$. thuringiensis subsp. kurstaki isolate to the red palm weevil, $R$. ferrugineus.}

The $4^{\text {th }}, 8^{\text {th }}$ and $11^{\text {th }}$ were used to evaluate the biological activity of $B$. thuringiensis subsp. kurstaki isolate. The larvae and adults were exposed to the bacterial-treated shreds sugarcane for 2 days then to untreated shreds sugarcane for 5 days. The bioassay data for the bacterium isolate against red palm weevil were recorded after 1 to 7days. Data in Table (3) showed that the accumulative mortality percentage in the $4^{\text {th }}$ instar larvae caused by B.t subsp. kurstaki ranged from 0.01 to $22.29 \%$ after 7 days post treatment. Meanwhile, mortality did not occur in the $8^{\text {th }}$ and $11^{\text {th }}$ instar larvae within any of the tested concentrations of $B . t$ isolate. The $\mathrm{LC}_{50}$ value for $4^{\text {th }}$ instar larvae was $3.1 \times 10^{10}$ spores $/ \mathrm{ml}$ (Table, 4$)$.

This finding is matching with Manachini et al., 2009 which tested the efficacy of the entomopathogenic bacterium $B$. thuringiensis to control the red palm weevil, $R$. ferrugineus in laboratory. They stated that although there were evidences indicating midgut damage and feeding inhibition among larvae that survived the treatments, results showed that the activity of $B$. thuringiensis against $R$. ferrugineus immature stages was low. On the contrary, Sivasupramaniam et al., 2007 found differences in susceptibility of the RPW to $B$. thuringiensis. However, a larval growth inhibition was observed for the red palm weevil and an interaction with hemocytes was primarily 
described, showing that the bacterium was able to grow in the hemolymph when ingested by the larvae (Manachini et al., 2011).

The growth of the gram-positive B. subtilis and $B$. thuringiensis is inhibited by the polar extracts of red palm weevil adults and large larvae (El-Sufty et al., 2007).

Table 3. Accumulative mortality of different instar larvae of red palm weevil by using B. thuringiensis subsp. Kurstaki after 7days.

\begin{tabular}{|c|c|c|c|}
\hline \multirow{2}{*}{$\begin{array}{c}\text { Concentration } \\
\text { Spores } / \mathrm{ml}\end{array}$} & \multicolumn{3}{|c|}{$\%$ mortality of developmental stage } \\
\cline { 2 - 4 } & $4^{\text {th }}$ instar larvae & $8^{\text {th }}$ instar larvae & $11^{\text {th }}$ instar larvae \\
\hline $3 \times 10^{9}$ & 22.29 & 0.00 & 0.00 \\
\hline $3 \times 10^{8}$ & 6.45 & 0.00 & 0.00 \\
\hline $3 \times 10^{7}$ & 1.15 & 0.00 & 0.00 \\
\hline $3 \times 10^{6}$ & 0.12 & 0.00 & 0.00 \\
\hline $3 \times 10^{5}$ & 0.01 & 0.00 & 0.00 \\
\hline
\end{tabular}

Table 4. $\mathrm{LC}_{50}$ values of $B$. thuringiensis subsp. Kurstaki against $4^{\text {th }}$ instar larvae of the RPW.

\begin{tabular}{|c|c|c|c|c|c|}
\hline \multirow{2}{*}{ Treated stage } & \multirow{2}{*}{$\begin{array}{c}\text { LC50 } \\
(\text { spores } / \mathrm{ml})\end{array}$} & \multicolumn{2}{|c|}{ 95\% fiducial limits } & \multirow{2}{*}{ Intercept } & Slope \\
\cline { 3 - 4 } & & & Upper & & $0.854 \pm$ \\
& $3.1 \times 10^{10}$ & $5.2 \times 10^{9}$ & $9.4 \times 10^{12}$ & $0.756 \pm$ \\
$4^{\text {th }}$ instar larvae & & & & 0.939 & 0.230 \\
\hline
\end{tabular}

\subsection{Pathogenicity of entomopathogenic nematode, $H$. bacteriophora-HP- 88 to the red palm weevil.}

The effects of $H$. bacteriophora-HP-88 on mortality of $R$. ferrugineus instar larvae and adults were investigated. The different instar larvae and adults were expose to $50 \mathrm{ml}$ water suspension of entomopathogenic nematode at 250,500,1000, 1500 and $2000 \mathrm{IJs} / \mathrm{ml}$. Observations were recorded after 24 hour till 9 days posttreatment. Data in Table (5) indicated that high virulence of tested nematode to $4^{\text {th }}$ instar larvae and adults after 9 days of treatments. H. bacteriophora-HP-88 looked the most effective nematode against the $4^{\text {th }}$ instar larvae because it achieved $100 \%$ mortality at all tested concentrations.

Meanwhile, the $8^{\text {th }}$ and $11^{\text {th }}$ instar larvae were less susceptible to nematode infection than $4^{\text {th }}$ instar larvae and adults. The nematode was more effective on the $8^{\text {th }}$ instar larvae than the $11^{\text {th }}$ instar larvae. Mortality in $8^{\text {th }}$ and $11^{\text {th }}$ instar larvae ranged from 34.71 to $85.20 \%$ and 16.54 to $67.94 \%$ due to nematode, $H$. bacteriophora-HP-88 treatment after 9 days, respectively. 
The third stage of nematode juveniles of infect and kill larvae (Faleiro, 2006), due to the gram- negative bacterium, Xenorhabdus nematophila (Poinar and Thomas) (Enterobacteraceae), carried in its gut. Indeed, the adults and larvae of the red palm weevil have no antimicrobial activities against gram-negative bacteria. However, limitation in the use of $S$. carpocapsae against red palm weevil for the inability to complete its life cycle and to reproduce inside the weevil, possibly due to some unknown inhibitory substances produced by the red palm weevil.

The higher susceptibility to the nematode by the small larvae rather than the large larvae also supports our findings. Confirming Aronson and Shai (2001) also, stated that methanol extracts of the small larvae do not show any antimicrobial activity, thus suggesting that they are the most susceptible stages to diseases.

Table 5. Accumulative mortality of different stages of red palm weevil by using $H$. bacteriophora-HP-88 after 9 days.

\begin{tabular}{|c|c|c|c|c|}
\hline \multirow{2}{*}{$\begin{array}{c}\text { Concentration } \\
\text { IJs/ml }\end{array}$} & \multicolumn{4}{|c|}{$\%$ mortality of the different stages } \\
\cline { 2 - 5 } & $4^{\text {th }}$ instar larvae & $8^{\text {th }}$ instar larvae & $\begin{array}{c}11^{\text {th }} \text { instar } \\
\text { larvae }\end{array}$ & \multirow{2}{*}{ Adults } \\
\hline 250 & 100 & 34.71 & 16.54 & 72.43 \\
\hline 500 & 100 & 53.44 & 31.10 & 85.88 \\
\hline 1000 & 100 & 71.42 & 49.46 & 94.00 \\
\hline 1500 & 100 & 80.13 & 60.53 & 96.68 \\
\hline 2000 & 100 & 85.20 & 67.94 & 97.90 \\
\hline
\end{tabular}

Table 6. LC50 values of $H$. bacteriophora-HP-88 against instar larvae and adults of the red palm weevil.

\begin{tabular}{|c|c|c|c|c|c|}
\hline \multirow{2}{*}{ Developmental stages } & \multirow{2}{*}{$\begin{array}{c}\mathrm{LC}_{50} \\
(\mathrm{IJs} / \mathrm{ml})\end{array}$} & \multicolumn{2}{|c|}{ 95\%fiducial limits } & \multirow{2}{*}{ Intercept } & \multirow{2}{*}{ Slope } \\
\hline & & Lower & Upper & & \\
\hline $8^{\text {th }}$ instar larvae & 435.16 & 192.09 & 649.87 & $\begin{array}{c}0.906 \pm \\
1.204\end{array}$ & $\begin{array}{r}1.552 \pm \\
0.416\end{array}$ \\
\hline $11^{\text {th }}$ instar larvae & 1045.34 & 662.39 & 205.74 & $\begin{array}{c}0.844 \pm \\
1.221 \\
\end{array}$ & $\begin{array}{c}1.376 \pm \\
0.413 \\
\end{array}$ \\
\hline Adults & 167.90 & 38.15 & 273.24 & $\begin{array}{c}0.065 \pm \\
1.786\end{array}$ & $\begin{array}{r}2.276 \pm \\
0.666\end{array}$ \\
\hline
\end{tabular}


Table 7. $\mathrm{LT}_{50}$ values of the red palm weevil stages treated with different concentrations of $H$. bacteriophora-HP-88 after 9 days.

\begin{tabular}{|c|c|c|c|c|}
\hline \multirow{2}{*}{$\begin{array}{c}\text { Concentration } \\
\text { IJs/ml }\end{array}$} & \multicolumn{4}{|c|}{ LT $_{50}$ values (days) } \\
\cline { 2 - 5 } & $4^{\text {th }}$ instar larvae & $8^{\text {th }}$ instar larvae & $1^{\text {th }}$ instar larvae & Adults \\
\hline 250 & 4.32 & 11.01 & 16.02 & 6.39 \\
\hline 500 & 3.84 & 8.55 & 11.02 & 5.76 \\
\hline 1000 & 3.32 & 6.61 & 9.38 & 4.06 \\
\hline 1500 & 2.84 & 5.03 & 7.89 & 3.31 \\
\hline 2000 & 2.03 & 4.07 & 5.75 & 2.99 \\
\hline
\end{tabular}

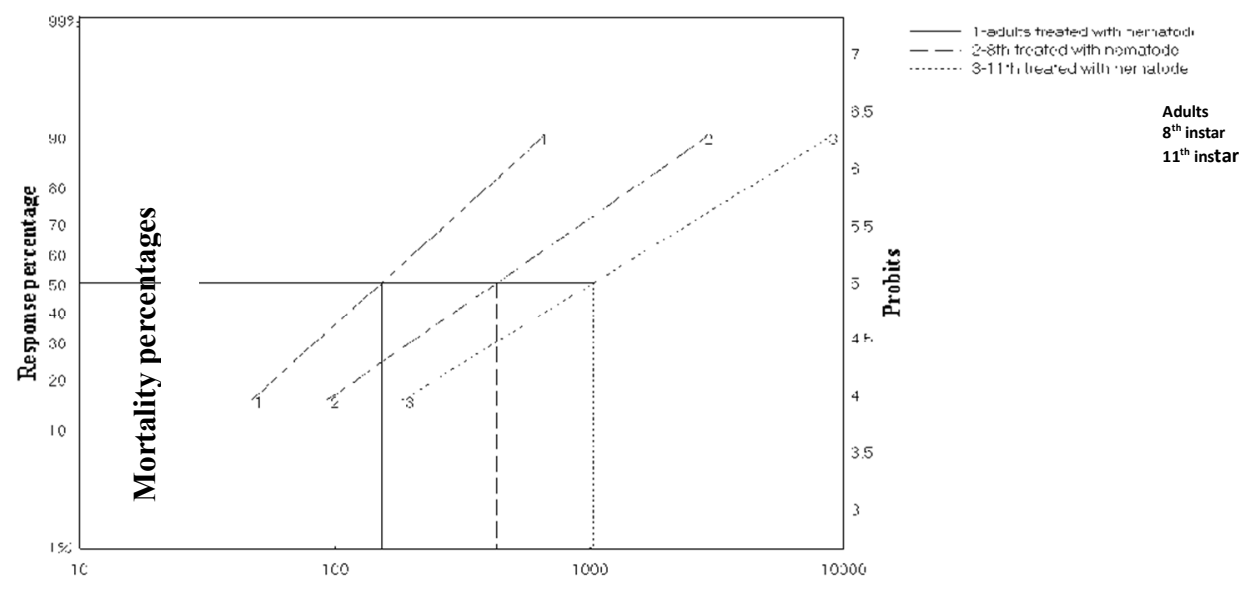

Log. Concentration $(\mathrm{IJ} / \mathrm{ml})$

Fig. 1. Mortality regression lines of the red palm weevil $\left(8^{\text {th }}, 11^{\text {th }}\right.$ larvae and adults) treated with different concentration of $H$.

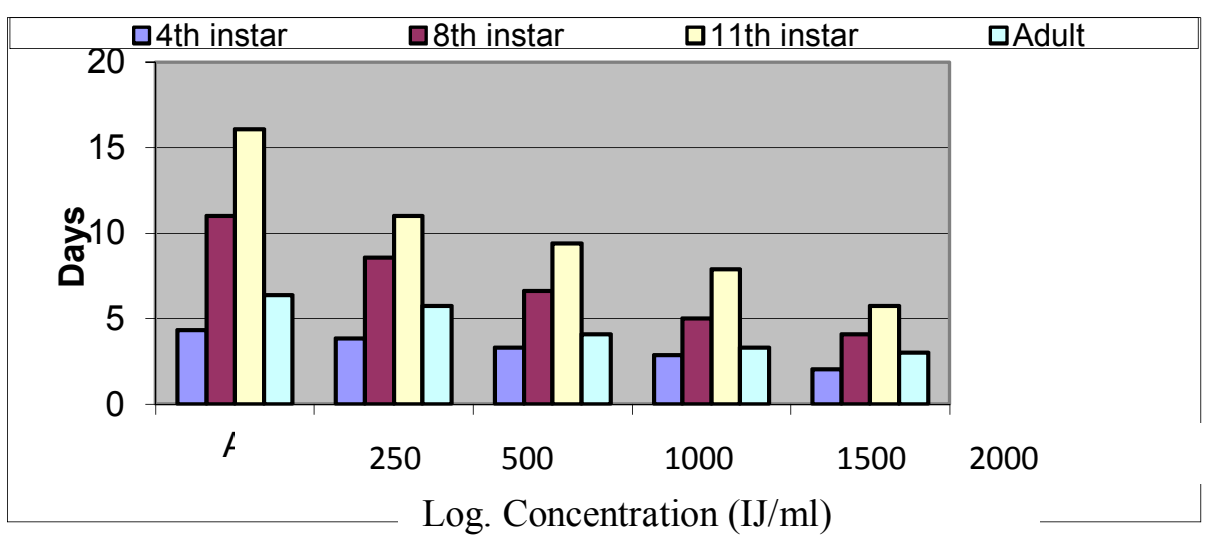

Fig. 2. LT 50 values of RPW developmental stages treated with different concentrations of nematode. 
Adults of $R$. ferrugineus were less susceptible to nematode infection than $4^{\text {th }}$ instar larvae. Mortality induced nematode to the adults ranged between $72.43 \%$ and $97.90 \%$ for the five tested concentrations (Table 5 and 6 ).

The $\mathrm{LC}_{50}$ value for nematode treatment against the $4^{\text {th }}$ instar larvae was not applicable for computing because this particular stage was very susceptible to tested nematode so that all nematode concentrations induced $100 \%$ mortality. However, LC 50 values for $8^{\text {th }}, 11^{\text {th }}$ and adults were $435.16,1045.34$ and $167.90 \mathrm{IJ} / \mathrm{ml}$, respectively (Table, 6). Results in Table (10) and Fig. (10) indicated that the LT50 values for the $4^{\text {th }}$ instar larvae were $4.32,3.84,3.32,2.84$ and 2.03 days at concentrations of $250,500,1000,1500$ and $2000 \mathrm{IJs} / \mathrm{ml}$. The $\mathrm{LT}_{50}$ values were 11.01 , $8.55,6.61,5.03$ and 4.07 days in $8^{\text {th }}$ instar larvae at the same concentrations. Meanwhile, in the $11^{\text {th }}$ instar larvae the $\mathrm{LT}_{50}$ values were $16.02,11.02,9.38,7.89$ and 5.75 days at the same concentrations. Table (10) and Fig. (10) showed that the $L T_{50}$ values were increased with increasing the larval stage. The $L T_{50}$ values (Table, 10) for the experimented adults were $6.39,5.76,4.06,3.31$ and 2.99 days at the same concentrations.

Our results agree with Abbas and Hanounik (1999), they reported that Steinernema riobravis, S. carpocapsae and Heterorhabditis sp. were virulent to both larval and stages of $R$. ferrugineus in laboratory tests. Saleh and Alheji (2003) reported that in the laboratory, $H$. indica from Saudi Arabia caused 100, 70 and 75\% mortality in young, grown larvae and adults of $R$. ferrugineus, respectively.

\section{Filed evaluations of the effectiveness of the entomopathogens against red palm weevil, $R$. ferrugineus.}

Field experiments using that the fungus, M. anisopliae; bacterium, $B$. thuringiensis and nematode, $H$. bacteriophora-HP-88 showed no external sign of recovery from the three infestation levels (Table, 14). Results cleared that the fungus, M. anisopliae; bacterium, B. thuringiensis and nematode, H. bacteriophora-HP-88 were not good candidates as a bio-control agent for red palm weevil, $R$. ferrugineus. Besides, these agents showed little effects on the pest in laboratory and no effect due to field applications. Therefore, the fungus, M. anisopliae; bacterium, B. thuringiensis and nematode, $H$. bacteriophora-HP-88 need more studies as bioagents used against the red palm weevil. Thus, we cannot completely discord its use in biological controls. 
Table 14. Injection of B. thuringiensis, M. anisopliae and H. bacteriophora-HP-88.

\begin{tabular}{|c|c|c|c|c|c|}
\hline & \multirow{2}{*}{$\begin{array}{c}\text { Type of } \\
\text { entomopathogen }\end{array}$} & $\begin{array}{c}\text { Number of } \\
\text { treated } \\
\text { palms }\end{array}$ & Mean number & \multicolumn{3}{|c|}{$\begin{array}{c}\text { \% percentage of palm recovery } \\
\text { after tubes/palm }\end{array}$} & $\begin{array}{c}\text { One } \\
\text { week }\end{array}$ & $\begin{array}{c}\text { Two } \\
\text { weeks }\end{array}$ & $\begin{array}{c}\text { Three } \\
\text { weeks }\end{array}$ \\
\hline $\begin{array}{c}\text { M. anisopliae }\left(10^{8}\right. \\
\text { spores/ml) }\end{array}$ & 7 & $5-8$ & 0 & 0 & 0 \\
\hline $\begin{array}{c}\text { B. thuringiensis }\left(10^{8}\right. \\
\text { spores/ml) }\end{array}$ & 5 & $5-8$ & 0 & 0 & 0 \\
\hline H. bacteriophora-HP-88 & 5 & $5-8$ & 0 & 0 & 0 \\
\hline
\end{tabular}

* Experiments were carried out starting May 2014. The entomopathogens were applied at different times and different trees.

In conclusion, in this study, we have studied the infection of red palm weevil stages by the fungus, $M$. anisopliae, bacteria, B.t subsp. Kurstaki and nematode, $H$. bacteriophora-HP-88. Data in this study showed that the fungus, M. anisopliae was less virulent to eggs, $4^{\text {th }}$ instar larvae and adults stage of red palm weevil. Meanwhile, $8^{\text {th }}, 11^{\text {th }}$ instar larvae and pupae were most tolerant to M. anisopliae.

Our results showed that the activity of $B$. thuringiensis against red palm weevil was low.

mortality of red palm weevil stages infected by $H$. bacteriophora-HP-88 was increased with the increasing of concentrations under laboratory conditions.

Field application obtained that M. anisopliae, B. thuringiensis subsp. kurstaki and $H$. bacteriophora-HP-88 showed no external sign of recovery from the three infestation levels. Therefore, the fungus, M. anisopliae; bacterium, B. thuringiensis and nematode, $H$. bacteriophora-HP-88 need more studies as bio-agents used against the red palm weevil. Thus, we cannot completely discord its use in biological controls.

\section{REFRENCES}

1. Abbas, M. S. T. and S. P. Hanonik. 1999. Pathogenicity of entomopathogenic nematodes to red palm weevil, Rhynchophorus ferrugineus. Intern. J. Nematol., 9(1): 84-86.

2. Abbott, W.S. 1925. A method of computing the effectiveness of an insecticide. J. Econ. Entomol 18: 265-267.

3. Aronson, A. and Y. Shai. 2001. Why Bacillus thuringiensis insecticidal toxins are so effective: unique features of their mode of action. Fems Microbiology Letters, 195: 1-8.

4. Attathom, T.; W. Chongrattanameteekul; J. Chanpaisang and R. Siriyan. 1995. Morphological diversity and toxicity of delta-endotoxin produced by various strain of Bacillus thuringiensis. Bull. Intemol. Res. 5: 167-173. 
5. Dembilio, O.; E. Q. Moraga, C. S. Alvarez and J. A. Jacas. 2010. Potential of an indigenous strain of the entomopathogenic fungus Beauveria bassiana as a biological control agent against the red palm weevil, Rhynchophorus ferrugineus. J. Inverteb. Pathol. 104, 214-221.

6. El-Sufty, R; S. A. Al-Awash; A. M. Al-Amiri ; A. S. Shahdad ; A. H. Al-Bathra and S. A. Musa. 2007. Biological control of red palm weevil, Rhynchophorus ferrugineus (Col.:Curculionidae) by the entomopathogenic fungus Beauveria bassiana in United Arab Emirates. Acta-Horticulturae. (736): 399-404.

7. Faleiro J.R. 2006. A review of the issues and management of the red palm weevil Rhynchophorus ferrugineus (Coleoptera: Rhynchophoridae) in coconut and date palm during the last one hundred years. Int. J. Trop. Insect Sci., 26:135-154.

8. Finney, D.J. 1971. Probit Analysis, a Statistical Treatment of the Sigmoid Response Curve, $6^{\text {th }}$ Ed., Cambridge Univ. Press, Cambridge, England.

9. Gindin, G; S. Levski; I. Glazer and V. Soroker. 2006. Evaluation of the entomopathogenic fungi Metarhizium anisopliae and Beauveria bassiana against the red palm weevil Rhynchophorus ferrugineus. Phytoparasitica-. 34(4): 370379.

10. Hanounik, S. B. 1998. Steinernematides and Heterorhabditides as biological control agents for the red palm weevils (Rhynchophorus ferrugineus) Sultan Qabus Univ. J. Scientific Res. Agric. Sci. 3:95-102.

11. Kaakeh, W.; M. Aboui-Anour and A. A.Khamis. 2001. Mass rearing of the red palm weevil, Rhynchophorus ferrugineus (Oliv.) on sugarcane and artificial diets for laboratory studies. Pp.344-357. proceedings of the Second International Conference on Date Palm (refereed), Al-Ain, UAE.

12. Kaya, H. K. and S. P. Stock. 1997. Techniques in insect nematology. In: Lacey, L. (ed.)

13. Manachini, B.; M. Vazzana; M. Celi and V. Arizza; 2011. Bacillus thuringiensis treatment alters larval growth, hemocytes and modulation of $\mathrm{Hsp70}$ in Rhynchophorus ferrugineus. IOBC/WPRS Bulletin 66: 53-57. 328.

14. Manachini, B.; P. L.Bue; E. Peri; S. Colazza; R. U. Ehlers; N. Crickmore; J. Enkerli; I. Glazer; M. Lopez-Ferber and C. Tkaczuk (2009). Potential effects of Bacillus thuringiensis against adults and older larvae of Rhynchophorus ferrugineus. IOBC/WPRS Bulletin, 45: 239-242.

15. Merghem, A. 2011. Susceptibility of red palm weevil, Rhynchophorus ferrugineus (Olivier) for the green muscardine fungus, Metarhizium anisopliae (Metsch.) in the laboratory ad in palm trees orchards. Egyptian J. Biol. Pest Control 21(2): 179-183. 
16. Saleh, M. M. E and M. Alheji. 2003. Biological control of red palm weevil with entomopathogenic nematodes in the Eastern province of Saudi Arabia. Egyptian Journal of Biological Pest Control. 2003; 13(1/2): 55-59.

17. Shaiju, S.; R. Kumar and C. Gokulapalan. 2003. Occurrence of Beauveria sp. on red palm weevil, Rhynchophorus ferrugineus (Oliv.) of coconut. Insect Environ. 9(2): 66-67.

18. Shapiro, D. I.; M. Jackson; C. C. Reilly and M. W. Hotchkiss. 2004. Effects of combining an entomopathogenic fungi or bacterium with entomopathogenic nematodes on mortality of Curculio caryae (Coleoptera: Curculionidae). Biol. Control 30, 119-126.

19. Shapiro-Ilan, D. I.; D. H. Gouge; A. M. Koppenhofer. 2002. Factors affecting commercial success: case studies in cotton, turf and citrus. In: Gaugler, R. (Ed.), Entomopathogenic Nematology. CABI, New York, pp. 333-356.

20. Sivasupramaniam S.; G. p. Head; L. English; Y. J. Li and T. T. Vaughn 2007. A global approach to resistance monitoring. J. Inverteb. Pathol., 95: 224-226.

21. Thom, C. and K. B Raper. 1945. Amanual of Aspergillus Willamas and Wilkins Co. Batimore, Mol.

22. Vitale, A.; V. Leone; L. Torta; S. Burruano and G. Polizzi. 2009. Prove preliminari di lotta biologica con Beauveria bassianae Metarhizium anisopliaenei confronti del punteruolo rosso, pp. 169-172. In: La ricerca scientifica sul punteruolo rosso e gli altri fitofagi delle palme in Sicilia, Vol.1.- Regione Siciliana, Assessorato Agricoltura Foreste Dipartimento Interventi Infrastrutturali, Italy (abstract in English). 


\section{تقيمي بعض الممرضات الحشرية على سوسة النخيل الحمراء تحث الظروف المعملية والحقلية}

$$
\begin{aligned}
& \text { محمد عبد السلام على' - حسن قاسم بخيت - ' مدئ }
\end{aligned}
$$

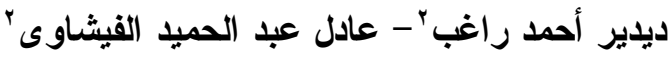

$$
\begin{aligned}
& 1 \text { - معهـ بحـــــوث وقــاية النبــاتــات - الدقي - جـــــــزة - مصر } \\
& \text { r- قسم وقاية النبات - كلية الزراعة - جامعة الزقازيق - مصر }
\end{aligned}
$$

تم إنجاز هذا العمل بمنطقة القصاصين- محافظة الإسماعيلية- مصر ، لتقييم كفاءة ثلاثة

ممرضات حشرية ضد الأطوار المختلفة لسوسة النخيل الحمر اء تحت الظروف المعملية والحقلية.

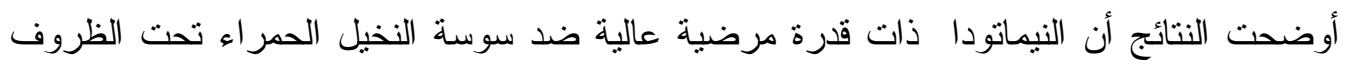
المعلية. وعلى الجانب الاخر كانت فعالية فطر الميتاريزيم انيزوبليا وبكتيريا الباسيلس ثورينجينسيز

منخفضة.

ومن ناحية أخرى، أوضحت التحارب الحقلية أن المعاملة بنيماتودا الهيتيروربديتس وفطر

الميتاريزيم انيزوبليا وبكتيريا الباسيلس ثورينجينسيز لم تظهر أي نسبة شفاء فى الأشجار المعاملة. 